\title{
Acceleration of Blue Swimming Crab (Portunus pelagicus) Larval Development by Phytoecdysteroid
}

\author{
Fakhirah Ahmad, Yushinta Fujaya*, Dody Dharmawan Trijuno, and Siti Aslamyah \\ Fisheries Department, Faculty of Marine Sciences and Fisheries, Hasanuddin University, Kampus UNHAS Tamalanrea \\ Makassar 90245, INDONESIA \\ *Correspondence to: yushinta.fmuskar@gmail.com
}

\begin{abstract}
Fakhirah Ahmad, Yushinta Fujaya, Dody Dharmawan Trijuno, and Siti Aslamyah. 2015. Acceleration of Blue Swimming Crab (Portunus pelagicus) Larval Development by Phytoecdysteroid. Aquacultura Indonesiana, 16 (2): 50-55. Phytoecdysteroid is a mimic of hormone-like molt regulating hormone in arthropoda and crustacea. The aim of this research was to investigate the response of blue swimming crab (Portunus pelagicus) larvae on various doses $/ 100 \mathrm{~g}$ artificial diet) were used in this research. Larval development and survival rate were measured. The results showed that the larvae development rate increased of vitomolt enrichment in predigested artificial diet. Four doses of vitomolt $(0 ; 4 ; 40 ; 400 \mathrm{mg}$ in congruent with the dose of vitomolt. However, highest survival rate was found on $4 \mathrm{mg}$ vitomolt/100 $\mathrm{g}$ artificial diet $(P>0.05)$. Based on regression analysis, it is estimated the optimal dose of vitomolt for larval development rate and survival rate was about $23 \mathrm{mg} / 100 \mathrm{~g}$ of artificial diet. Vitomolt application in artificial diet could be used to accelerate the larval development rate in blue swimming crab.
\end{abstract}

Keywords: Crab; Larval development; Phytoecdysteroid; Portunus; Survival

\section{Introduction}

Blue swimming crab (Portunus pelagicus) is one of widely traded commercial crab around the world. The World bank (2012) reported that in 2008, Indonesia was ranked as the second largest producer of blue swimmer crab after China with a contribution about 20\%. Unfortunately, the increase in human needs and environmental pressures on marine biological resources result in the decline of Indonesia crab stocks annually by 20-30\% (Mahesa, 2010). Therefore, it is important to maintain and increase the natural blue swimming crab population whether by proper management, stock enhancement and cultivation. Cultivation of blue swimming crab may contributes into two ways, hatchery-raised seeds for stock enhancement and blue-crab grow-out perhaps to provide product directly for market consumption.

Lower survival rate of larvae is still the main problem of blue swimmer crab hatchery (Soundarapandian et al., 2007), which caused by various factors like disease (Govindasamy and Srinivasan, 2012; Talpur et al., 2011 a $2011^{\mathrm{b}}$ ), molting syndrome (Hamasaki et al., 2002) and cannibalism (Soundarapandian et al., 2007). Many efforts have been done to address these issues such as probiotics application for vibriopathogenic control and arrangement of natural diet amount and feeding time (Juwana et al., 2010). But, mortality is still high and survival rate is unstable.

Vitomolt is a formula from Morus alba, contain phytoecdysteroid for stimulating molting. Phytoecdysteroid is a mimics hormone like ecdysteroid in arthropod and crustacea. Ecdysteroids (zooecdysteroids) are steroid hormones that control molting, metamorphosis and reproduction of arthropods (Lafont and Dinan, 2003; Huberman, 2000). Ecdysteroids are probably the most abundant steroids in nature because they are produced not only by arthropods, but also by many plant species, namely phytoecdisteroid (Klein, 2004). Phytoecdisteroid could stimulate the synthesis of proteins in animals and humans, and to have adaptogenic, antimutagenic, hypocholesterolemic, immunostimulating, nutritive, and tonic properties (Lafont and Dinan, 2003). In this study, we investigated the response of Portunus pelagicus larvae on various dose of vitomolt (contain phytoecdysteroid) as supplemen enrichment in predigested artificial diet. Response of the blue crab on the vitomolt treatment were indicated by larval development and survival rate. 


\section{Materials and Methods}

\section{Broodstock collection}

Portunus pelagicus broodstock was obtained from fishermen around the Makassar Strait. The collected broodstock was brought into the backyard hatchery using styrofoam and aeration. Size of broodstock was about $110.2 \mathrm{~g}$ and $115.4 \mathrm{~mm}$ of outer carapace width. Hatching was performed in conical tank ( $250 \mathrm{~L}$ volume). After hatching, the larvae were selected by phototaxis movement and transferred into the 19 L conical container with $10 \mathrm{~L}$ of seawater $(30 \%)$ ). Stocking was performed at 50 zoeas/L.

\section{Larva rearing}

During rearing, the larvae were fed rotifers, artemia nauplii, and predigestion artificial diet. Feeding was performed 8 times a day, 2 times for life feed and 6 times for artificial feed. The daily feed dose shown in Table 1. Water quality were maintained at $30 \%$ of salinity, $31^{\circ} \mathrm{C}$ of temperature and 7.5 of $\mathrm{pH}$. Water was changed $20 \%$ of the total volume daily to keep the optimal water condition. Larvae rearing carried out for $11 \mathrm{~d}$ or until the larvae enter the megalopa stage.

\section{Feed preparation}

Commercial diet for shrimp larvae was used in this study. The feed composition was
$40.37 \%$ protein, $8: 56 \%$ fat, and $28.57 \%$ carbohydrate. Predigestion were performed by Bacillus subtilis $\left(2 \times 10^{8} \mathrm{CFU} / \mathrm{g}\right)$ for $13 \mathrm{~h}$ at room temperature $\left(30^{\circ} \mathrm{C}\right)$. Vitomolt enrichment was done by sprying various doses of vitomolt solution to the predigested artificial feed. Vitomolt solution was prepared from each doses of $0,4,40,400 \mathrm{mg}$ of vitomolt dissolved in $5 \mathrm{~mL}$ of $80 \%$ ethanol. The vitomolt-enriched predigested artificial diet was kept in refrigerator.

\section{Experimental design and data analysis}

This study is based on the completely randomized design with 4 treatments and 3 replicates (Gaspesz, 1991). The treatments of Vitomolt were: (A) control (without vitomolt), (B) $4 \mathrm{mg}$ vitomolt $/ 100 \mathrm{~g}$ artificial diet, (C) 40 $\mathrm{mg}$ vitomolt $/ 100 \mathrm{~g}$ artificial diet, and (D) $400 \mathrm{mg}$ vitomolt $/ 100 \mathrm{~g}$ food. Data collected in this study were larva development index (LDI) and survival rate of crab larvae before entering the megalopa stage. Larval development rate was observed every day for LDI determination based on the formula: $\mathrm{LDI}:\{(\mathrm{Zo} \times \mathrm{No})+(\mathrm{Zt} \times \mathrm{Nt})\} / \mathrm{N}$, which : $Z_{0}=$ zoea at earliar stage; $\mathrm{n}_{0}=$ number of earlier stage zoea; $Z_{t}=$ next stage zoea; $n_{t}=$ number of next stage zoea; $\mathrm{N}=$ total number of zoea sampled (Redzuari et al., 2012). The Morphological characteristics and Larval Development Index (LDI) of blue swimmer crab refer to Fujaya et al. (2014) (Table 2).

Table 1. Standard diet dose of blue swimmer crab larvae (P. pelagicus) for each stage

\begin{tabular}{lcccc}
\hline \multicolumn{1}{c}{ Diet type } & Zoea-1 & Zoea-2 & Zoea-3 & Zoea-4 \\
\hline Rotifer (ind/mL) & 10 & 10 & - & - \\
Artemia nauplii (ind/mL) & - & - & 10 & 10 \\
Artificial diet (mg/L) & 2.5 & 5 & 7.5 & 10 \\
\hline
\end{tabular}

Table 2. Morphological characteristics and Larval Development Index (LDI) of blue swimmer crab

\begin{tabular}{|c|c|c|}
\hline Stadia & Morphological Characteristics & LDI \\
\hline Zoea-1 (Z1) & Eyes sessile, 5 segmented abdomen with a fork resembles a telson & $1-1.5$ \\
\hline Zoea-2 (Z2) & $\begin{array}{l}\text { Eyes stalked, abdomen and telson are in similar condition with the ones in the } \\
\text { previous stage }\end{array}$ & $1.6-2.5$ \\
\hline Zoea-3 (Z3) & $\begin{array}{l}\text { Eyes stalked, } 6 \text { segmented abdomen, paired pleopodbuds at ventral posterior, telson } \\
\text { similar to previous stage }\end{array}$ & $2.6-3.5$ \\
\hline Zoea-4 (Z4) & $\begin{array}{l}\text { Eyes stalked, } 6 \text { segmented abdomen, pleopod buds well developed, telson similar to } \\
\text { previous stage }\end{array}$ & $3.6-4.5$ \\
\hline Megalopa (M) & $\begin{array}{l}\text { More like crabs than zoea, the carapace gets rounded according to its length, first } \\
\text { pereiopod appears in the tip of the upper arm, abdomen in the posterior is still long }\end{array}$ & $4.6-5.5$ \\
\hline
\end{tabular}


Table 3. Larval development rate of blue swimmer crab based on larval development index.

\begin{tabular}{|c|c|c|c|c|c|c|c|c|c|c|c|c|}
\hline \multirow{2}{*}{\multicolumn{2}{|c|}{$\begin{array}{c}\text { Treatment } \\
(\mathrm{mg} \text { vit } / 100 \mathrm{~g} \text { diet })\end{array}$}} & \multicolumn{10}{|c|}{ Age of larvae (d) } & \multirow[b]{2}{*}{11} \\
\hline & & 1 & 2 & 3 & 4 & 5 & 6 & 7 & 8 & 9 & 10 & \\
\hline \multirow[t]{2}{*}{$\mathbf{0}$} & LDI & 1 & 1 & 1.6 & 2.0 & 2.0 & 2.4 & 2.6 & 3.0 & 3.0 & 3.0 & 3.7 \\
\hline & Std & $\mathrm{Z} 1$ & $\mathrm{Z} 1$ & $\mathrm{Z} 2$ & $\mathrm{Z} 2$ & $\mathrm{Z} 2$ & $\mathrm{Z} 3$ & $\mathrm{Z3}$ & $\mathrm{Z3}$ & $\mathrm{Z3}$ & $\mathrm{Z3}$ & $\mathrm{Z4}$ \\
\hline \multirow[t]{2}{*}{4} & LDI & 1 & 1 & 1.4 & 2.0 & 2.0 & 2.4 & 2.7 & 3.0 & 3.0 & 3.3 & 3.7 \\
\hline & Std & $\mathrm{Z1}$ & $\mathrm{Z1}$ & $\mathrm{Z} 2$ & $\mathrm{Z} 2$ & $\mathrm{Z} 2$ & $\mathrm{Z} 2$ & $\mathrm{Z3}$ & $\mathrm{Z3}$ & $\mathrm{Z3}$ & $\mathrm{Z} 4$ & $\mathrm{Z} 4$ \\
\hline \multirow[t]{2}{*}{40} & LDI & 1 & 1 & 1.4 & 2.0 & 2.1 & 2.6 & 2.5 & 3.0 & 3.2 & 3.6 & 4.0 \\
\hline & Std & $\mathrm{Z1}$ & $\mathrm{Z} 1$ & $\mathrm{Z} 2$ & $\mathrm{Z} 2$ & $\mathrm{Z3}$ & $\mathrm{Z} 3$ & $\mathrm{Z3}$ & $\mathrm{Z3}$ & $\mathrm{Z} 4$ & $\mathrm{Z} 4$ & $\mathrm{Z} 4$ \\
\hline \multirow[t]{2}{*}{400} & LDI & 1 & 1 & 1.3 & 2.0 & 2.0 & 2.3 & 2.5 & 3.0 & 3.1 & 3.5 & 3.9 \\
\hline & Std & Z1 & $\mathrm{Z1}$ & $\mathrm{Z} 2$ & $\mathrm{Z2}$ & $\mathrm{Z} 2$ & $\mathrm{Z} 3$ & $\mathrm{Z3}$ & $\mathrm{Z3}$ & $\mathrm{Z4}$ & $\mathrm{Z4}$ & $\mathrm{Z} 4$ \\
\hline
\end{tabular}

Z1 (Zoea-1); Z2 (Zoea-2); Z3 (Zoea-3); Z4 (Zoea-4)

Survival rate was counted using formula $\mathrm{SR}=$ $(\mathrm{Nt} / \mathrm{No})$ x 100, which: SR= Survival Rate (\%); $\mathrm{Nt}=$ Number of alive larva at the end of research (ind.); and $\mathrm{N}_{0}=$ Number of larva at the beginning of research (ind.). All data were analyzed by one way analysis of variance (ANOVA) and WTuckey test, while the optimal vitomolt dose estimation was performed using regression analysis. All probability values were set at 0.05 level of significance.

\section{Results}

\section{Larva development rate}

Larva of blue swimmer crab succeeded their development until zoea-4. Application of vitomolt at doses above $4 \mathrm{mg} / 100 \mathrm{~g}$ artificial diet accelerated larval development as can be seen on the Table 3. Vitomolt of $40 \mathrm{mg} / 100 \mathrm{~g}$ of feed showed the highest developmental rate. In this treatment, he larva reached zoea- 3 on day-5, the fastest development compared to other treatments. On the other hand, the lowest developmental rate was in the group of larva with no addition of vitomolt.

\section{Survival Rate}

Highest survival rate $(10.6 \%)$ of the blue crab larva was observed in the treatment of $4 \mathrm{mg}$ vitomolt/100 $\mathrm{g}$ diet and the lowest survival rate $(0.93 \%)$ was found in the treatment of $40 \mathrm{mg}$ treatment/100 $\mathrm{g}$ diet (Table 4). Analysis of variance (ANOVA) on the effect of the treatment was significantly $(P<0.05)$ affected the survival rate of the blue crab larva, then the Tuckey test showed that the treatment of $4 \mathrm{mg}$ vitomolt $/ 100 \mathrm{~g}$ diet was significantly different $\quad(\operatorname{Sig}<0.05)$ compared to other treatment on the survival rate.of the blue crab larva.
Table 4. Survival rate (\%) of $P$. pelagicus larvae on various treatments of vitomolt.

\begin{tabular}{lc}
\hline \multicolumn{1}{c}{ Treatment } & Survival Rate (\%) \\
\hline A. $0 \mathrm{mg}$ vitomolt $/ 100 \mathrm{~g}$ diet & $1.73 \pm 0.31^{\mathrm{a}}$ \\
B. $4 \mathrm{mg}$ vitomolt $/ 100 \mathrm{~g}$ diet & $10.6 \pm 4.73^{\mathrm{b}}$ \\
C. $40 \mathrm{mg}$ vitomolt/100 g diet & $0.93 \pm 0.31^{\mathrm{a}}$ \\
D. $400 \mathrm{mg}$ vitomolt/100 g diet & $2.8 \pm 1.22^{\mathrm{a}}$ \\
\hline Different letters indicate significant difference $(P$ \\
<0.05) of survival rate of larvae
\end{tabular}

Larva in all the treatments have succeded reached the megalopa phase. However, the highest survival rate of blue crab larva was found in the treatment of $4 \mathrm{mg}$ vitomolt $/ 100 \mathrm{~g}$ of artificial diet (Figure 1). Value of $\mathrm{R}^{2}=0.240$ show that there is about $76 \%$ affecting the survival rate is in addition to the dose of vitomolt.

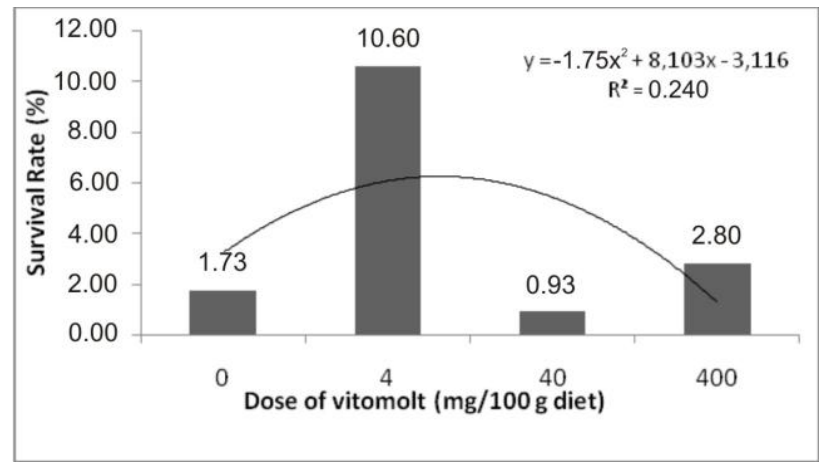

Figure 1. Survival rate (\%) of blue swimmer crab larvae in four vitomolt treatments after $11 \mathrm{~d}$ of rearing $(P<0.05)$.

Since the range of treatment concentrations were wide which resulted also in broad range of survival rates, optimal concentration is necessary to be estimated by analysis of regression. Calculation from the regression equation showed that optimal concentration was $23 \mathrm{mg}$ of vitomolt / $100 \mathrm{~g}$ diet. 
It is assumed that this optimal concentration may produces high survival rate of the blue crab larva.

\section{Discussion}

Vitomolt contains phytoecdysteroid. Phytoecdysteroid is an hormone which contributes in controlling molting in arthropods and crustaceans (Bakrim et al., 2008). This study showed that addition of vitomolt on artificial diet affected the developmental rate of blue swimmer crab larva. The vitomolt dose was in line with the developmental rate of the crab larva. As the dose increases, the rate of developmental stages of the crab was also faster. Azra et al. (2012), also reported that the adding of 20 Hydrocyecdyson into rearing water media of bule swimming crab larva could stumulate high molting.

Despite faster the developmental rate of larva, ecdysteroid hormones may also increase the metabolism of proteins in the cell that will encourage growth of crabs (Fujaya, 2011). An increase in growth of larval will encourage larval to actively molting, hence the larva developed faster into to the next stage.

Molting process begins when epidermal cells respond to hormonal changes through the rate of protein synthesis. An increased rate of protein synthesis due to stimulation by molting hormone which was added into artificial feed the larvae that will cause separation of epidermic and endocuticle which marked the start of the process of molting. The epidermic cells filled the gap between the layers with inactive molting fluid then, secreted specifiec lipoprotein to form new cuticle layer and it becomes part of epidermic layer of new exoskeleton. The cuticle layer produced amino acids and microfibrils. When the new exoskeleton has been prepared, muscle contraction and filling the air causes the body to bulge so long exoskeleton cracked along the lines. Water fills under the new soft-exoskeleton causes it to expands to accomodate the increase of body size (Meyer, 2007).

However, high doses of vitomolt has inverse affect, it inhibits larva growth. This phenomenon was showed in the treatment of 400 $\mathrm{mg}$ of vitomolt, that the development rate of the crab larva was lower compared to the other treatments. According to Turner and Bagnara (1976) that hormone is not only has a stimulating role but also can inhibits the physiological process. There is a negative feedback mechanism in hormonal works. High concentrations of hormone in the body fluid provide an indication for the inhibition of further hormone excretion in order to maintain equilibrium (homeostasis).

According to Fujaya (2011) that the precise dose of vitomolt will stimulate optimal molting activity whereas low doses of vitomolt is unadequate to stimulate molting and too high doses of the hormone may promote inhibition of molting process. Unstable concentration of ecdysteroid in the larval body will also produce unstable larval development rate which causes of size uniformity during larva development. The different sizes of larva will increase larval mortality due to cannibalism. Therefore, optimization of the vitomolt dose is important to accelerate the larval development rate.

There are many possible factors may produced low survival rate of the larvae during zoea phase. The death of the larvae in this research tends to occur at the beginning of the rearing period. This is allegedly due to the process adaptation of the larvae with the new media environment. High mortality in the zoea phase of larvae due to being highly sensitive state to the unfavorable environmental conditions.

In addition, deaths also occur by parasites attack. It is probably derive from the water larval rearing or by contaminated broodstock. The death was caused by parasites attack that was found on all parts of the larvae body. However, the type of parasite has not been identified. Accumulation of organic material on the tank bottom may stimulated parasite development.

A healthy larvae is indicated by active of molting activity. The larvae molts in each developmental changes from previous stadia to next stadia during metamorphosis period. Less molting activity is normally found in the unhealthy larva. Less molting activity means longer time of larvae in the same stage. This condition causes accumulation of organic and inorganic materials on the surface of the shell. As a result, excessive colonization of protozoa and other microorganisms on the body surface of the larvae, and this condition can be fatal when the larvae molting. During molting process as a new skin is soft can easily be infected by microorganisms, it causes mortality of larvae.

Water quality like temperature and ammonia also plays an important role in determining the survival rate of larvae. In this study, although the temparature in the optimal range $\left(28-32^{\circ} \mathrm{C}\right)$ but high fluctuation of daily temperature $\left( \pm 2-3^{\circ} \mathrm{C}\right)$ might affect larvae became 
stress and its contributed in low survival rate. Based on Boyd, (1990), if temperature suddenly changes by $3-4^{\circ} \mathrm{C}$, shock and mortality may occur. High ammonia concentration was other factor that may also contribute to low survival rate of the whole treatment groups. In this study, ammonia was also tend to be high, in the ranged of $1-2 \mathrm{mg} / \mathrm{L}$. Thus the water quality management is a very important factor in the future in addtition to improving quality of feed nutrition.

In conclusion, the larvae development rate was increased in congruent with the dose of vitomolt. However, optimal dose of vitomolt range between $4-40 \mathrm{mg} / 100 \mathrm{~g}$ diet. Concentration of $40 \mathrm{mg}$ vitomolt/100 $\mathrm{g}$ diet produced fastest larval development rate, but lower survival rate. In contrast, $4 \mathrm{mg}$ vitomolt/100 g diet produced highest survival rate than other dose. Regression analysis showed that $23 \mathrm{mg}$ vitomolt $/ 100 \mathrm{~g}$ diet is estimated to be the optimal dose for larval development rate and survival rate.

\section{Acknowledgement}

This study was financially supported by the Ministry of Education and Culture of Republic of Indonesian for the funding through Grant for Excellent Research for National Strategic. The authors wish to thanks Faculty of Marine Sciences and Fisheries Hasanuddin University for the rearing facilities.

\section{References}

Azra, M.N., J. Safiah, A.B.A. Munafi, and M. Ikhwanuddin. 2012. Effects of 20Hydroxyecdysone on early larval stages of Blue swimming crab's, Portunus pelagicus (Linnaeus, 1758). UMT 11th International Annual Symposium on Sustainability Science and Management 09th - 11th July 2012, Terengganu, Malaysia.

Bakrim, A., A. Maria, A. Sayah, R. Lafont, and N. Takvorian. 2008. Ecdysteroids in spinach (Spinacia oleracea L.): Biosiynthesis, transport and regulation of levels. Online Abstract. Plant Physiology and Biochemistry, 46 (10).

Boyd, C.E. 1990. Water Quality in Ponds for Aquaculture. Alabama: Birmingham Publishing Company.

Fujaya, Y. 2011. Growth and molting of mud crab administered by different doses of vitomolt. Jurnal Akuakultur Indonesia, 10(1), 24-28.

Fujaya, Y., D.D. Trijuno, A. Nikhlani, I. Cahyono, and Hasnidar. 2014. The use of Mulberry
(Morus alba) extract in the mass production of Blue swimming crab (Portunus pelagicus L.) larvae to overcome the mortality rate due to molting syndrome. Aquatic Science Technologi, 2 (1) ; 1-14.

Gaspersz, V. 1991. Experimental Design Method, Armico.Bandung, Indonesia.

Govindasamy, C. and R. Srinivasan. 2012. Association of bioluminescent bacteria from blue swimmer crab Portunus pelagicus (Linneaus, 1758). Asian Pacific Journal of Tropical Disease, S699S702.http://dx.doi.org/10.1016/S22221808(12)60246-1

Hamasaki, K., M.A. Suprayudi, and T. Takeuchi. 2002. Mass mortality during metamorphosis to megalops in the seed production of mud crab Scylla serrata (Crustacea, Decapoda, Portunidae). Fisheries Science, 68, 12261232.

Huberman. 2000. Shrimp endocrinology: a review. Aquaculture, 191, 191-208.

Juwana, S., Y.R. Ruyitno, Alfianzah, and Sujono. 2010. Utilization of artemia nauplii, supplemented diet and commercial probiotic, for production of crab seed (Portunus pelagicus). Oseanologi dan Limnologi di Indonesia, 36 (3): 259-279.

Klein, R. 2004. Phytoecdysteroids. Journal of the American herbalists guild. Fall/Winter: 18-28

Lafont, R. and L. Dinan. 2003. Practical uses for ecdysteroids in mammals including humans: and update. Journal of Insect Science, 3 (7):1-30, Available online: insectscience.org/3.7

Mahesa, R.W. 2010. Ekspor Rajungan Terancam Sertifikasi. Diakses dari: http://industri.kontan.co.id/news/eksporrajungan-terancam-sertifikasi-1

Meyer, J.R. 2007. Morphogenesis department of entomology. NC State University. www.morphogenesis.htm.

Redzuari, A., M.N. Azra, A.B. Abol-Munafi, Z.A. Aizam, Y.S. Hii, and M. Ikhwanuddin. 2012. Effects of Feeding Regimes on Survival, Development and Growth of Blue Swimming Crab, Portunus pelagicus (Linnaeus, 1758) Larvae. World Applied Sciences Journal, 18 (4), 472-478.

Soundarapandian, P., E. Thamizhazhagan, and N.J. Samuel. 2007. Seed Production of Commercially Important Blue swimming crab Portunus pelagicus (Linnaeus). Journal of Fisheries and Aquatic Science, 2, 302-309. http://dx.doi.org/10.3923/jfas.2007.302.309. 
Talpur, A.D., A.J. Memon, M.I. Khan, M. Ikhwanuddin, M.M.D. Daniel, and A.B. Abol-Munafi. 2011 ${ }^{\text {a }}$ A novel of gut pathogenic bacteria of Blue swimming crab Portunus pelagicus (Linneaus, 1958) and pathogenicity of Vibrio harveyi a transmission agent in larval culture under hatchery condition. Research Journal of Applied Sciences, 6 (2), 116-127. http://dx.doi.org/10.3923/rjasci.2011.116.127

Talpur, A.D., A.J. Memon, M.I. Khan, M. Ikhwanuddin, M.M.D. Daniel, and A.B. Abol-Munafi. 2011 ${ }^{\mathrm{b}}$. Pathogenicity and antibiotic sensitivity of pathogenic flora associated with the gut of Blue Swimming Crab Portunus pelagicus (Linneaus, 1958). Journal of Animal and Veterinary Advances, 10 (16), 2106-2119.

Turner, C.D. and J.T. Bagnara. 1976. Endokrinologi Umum. Jogyakarta: Airlangga University Press.

World Bank. 2012. Evaluation of New Fishery Performance Indicators (Fpis):A Case Study of The Blue Swimming Crab Fisheries In Indonesia and Philippines. International Bank for Reconstruction and Development / International Development Association. Washington DC 20433. 